\title{
25 Research Soure \\ Youth Friendly Reproductive Health Services Among Students of Mizan-Tepi University, South-western Ethiopia
}

Samuel Getachew Zewudie ( $\square$ samtingnew@gmail.com )

Mizan-Tepi University https://orcid.org/0000-0001-7867-8127

Lema Abate Adulo

Mizan-Tepi University

Abel Mandefro Sirna

Mizan-Tepi University

Abiyot Asres

Mizan-Tepi University

\section{Research}

Keywords: Knowledge, Attitude, Utilization, Youth friendly reproductive health services, Ethiopia

Posted Date: October 26th, 2020

DOI: https://doi.org/10.21203/rs.3.rs-96017/v1

License: @ (i) This work is licensed under a Creative Commons Attribution 4.0 International License. Read Full License 


\section{Abstract}

Background: Youth friendly reproductive health services are designed to entertain the unique needs of youth. Nevertheless, in developing countries like Ethiopia, knowledge, attitude and utilization of these services is very limited. This study was designed to assess the knowledge, attitude and the extent of utilization of youth friendly reproductive health services (YFRHS) and associated factors among students of Mizan-Tepi University, Southwestern, Ethiopia.

Method: A public University-based cross-sectional study was conducted between October and January 2019. Simple random sampling technique was used to select participants from target population. Descriptive analysis, Chi-square test and logistic regression model were employed to identify the factors associated with YFRHS.

Result: The results of descriptive analysis showed that about $55.4 \%$ of participants had no knowledge, $40.2 \%$ had negative attitudes and $61.2 \%$ had not practiced YFRHS. Majority 258(60.30\%) of the respondents were females and $209(48.80 \%)$ were in the age group of 21-22 years. Most of the respondents lack basic information and knowledge, and have no any YFRHS in their surroundings 220(51.4\%). Out of the 428 respondents, $57.9 \%$, $59.3 \%$, and $36.4 \%$ had never been practiced services related to VCT, family planning and contraception and treatment of sexually transmitted infections (STIs), respectively. The multivariable binary logistic regression result revealed that sex, age, religion, mother's and father's educational background, availability of YFRHS in the area and source of information had statistical significant effect on the knowledge, attitude and practices of students toward YFRHS. Male students were more likely to have knowledge and practicing experiences (OR = 1.847, $p$-value $=0.015)$ and $(O R=1.821, p$-value $=0.017)$ respectively, however they had less likely positive attitudes $(\mathrm{OR}=0.519, \mathrm{p}$-value $=0.010)$ compared to their counterpart females. Students from primary and above educated mothers and fathers were more likely to have knowledge, attitude and practicing experience compared to students from uneducated mothers and fathers.

Conclusion: The overall utilization, attitude and knowledge of YFRHS among study respondents' are lower and therefore, further efforts like availability of YFRHS providers and improvement of facility, and education related to the service to all young groups and allocation of appropriate time of services is essential.

\section{Plain English Summary}

Youth friendly service (YFS) is among the reproductive health services provided to young people to meet their health needs. Authors of this study assessed the knowledge, attitude and the extent of utilization of YFRHS and associated factors among students of Mizan-Tepi University using semi-structured questionnaire.

Participants were asked to answer questions to evaluate their awareness, attitude and utilization of YFRHS.

Of a total of 428 participants, $55.4 \%$ and $40.2 \%$ had no knowledge and negative attitude about YFRHS, respectively. Moreover, $61.2 \%$ had not practiced YFRHS at all. Particularly, 57.9\%, 59.3\%, and 36.4\% had never been utilized services related to voluntary counseling test (VCT), family planning and contraception and treatment of sexually transmitted infections (STIs), respectively. Sex, age, religion, mother's and father's educational background of the students, availability of YFRHS in the area and source of information had statistical significant effect on the knowledge, attitude and practices of the respondents toward YFRHS. 
In conclusion, practice, attitude and knowledge of YFRHS among study respondents' were found lower and these information can be used by both policy makers and health professionals to design a better way in providing YFRHS and improve awareness of youths in the country.

\section{Background}

Youth is a period of transition from childhood to adulthood and adolescence (from ages 10 to 19) is the process of attaining sexual and reproductive maturity $[1,2]$. Typical youth behaviors such as experimentation and risktaking make youths more vulnerable to pregnancy and STDs. Therefore, provision of youth-friendly sexual and reproductive health services is a fist step to ensure the psychological and biomedical needs of young individuals [3].

The World Health Organization (WHO) developed the adolescent friendly health services model in 2002, which was broadened to include the health needs of all young people [4, 5]. Youth friendly service (YFS) is among the reproductive health services provided to young people to meet their health needs. YFRHS includes sexual and reproductive health counseling, sexually transmitted infections (STIs), and voluntary counseling and testing services (VCT) $[6,4,7]$, and such services should be able to effectively attract and meet needs of young people comfortably and responsively, and succeed in retaining these young clients for a continuing care $[1,8,9]$.

Seventy-eight percent of youths live in developing countries and $60 \%$ of them are from sub-Saharan Africa, where the prevalence of HIV and other sexually transmitted infections (STIs), and unwanted pregnancy among young people is found to be high $[1,8,10]$. In Ethiopia, young people and adolescents in the age group of 10 to 24 constitute $22 \%$ of the total population, most of them live in rural areas and lack access and awareness to the reproductive health services $[7,11]$. The Ethiopian Ministry of Health (EMOH) has developed a 10 year National Adolescent and Youth Reproductive Health Strategy (NAYRHS) in 2015, utilization of the services among youths of the country is still low and remains facing several challenges associated with traits related to adolescent s' sexuality and their perception towards the YFS delivery centers. Research evidences from different parts of Ethiopia indicate that a lot of adolescents have still no access to services and young people are at risk of reproductive health problems. Recent findings from in rural areas indicated that YFRHS provision is limited in a few of government (public) health facilities in urban centres and many youth are less informed, less experienced, and less comfortable in accessing health services in their areas. Moreover, majority of the youth often lack basic YFRHS information and knowledge about the available services, and access to affordable and confidential services $[12,13,14,15,11]$. Therefore, most of the youths are at a particular risk for unwanted pregnancy and pregnancy related complications [16]. Moreover, reproductive tract infections (RTIs) including HIV/AIDS are other major health threats of young people of the country $[7,12,11]$. However, studies on the level of YFRHS utilization, knowledge and perceptions of youths towards YFRHS and associated factors are very limited in Ethiopia. Thus, this study was carried out with the objective of assessing YFRHS and associated factors among the students of Mizan-Tepi University, Tepi campus, southwestern Ethiopia.

\section{Methods}

\section{Study setting}


The study was conducted at Mizan-Tepi university Tepi campus which is situated in Tepi-611kms away from the capital of Ethiopia. Tepi campus is located in Yeki-Woreda at a mean elevation of 1,097 meters above sea level and at a latitude of $7^{\circ} 12^{\prime} \mathrm{N}$ and longitude of $35^{\circ} 27^{\prime} \mathrm{E}$. Tepi is the largest settlement in Yeki woreda and its climatic condition is characterized by higher temperature, higher moisture content and lower wind speed. The annual rain fall is 1547 with $22.4^{\circ} \mathrm{C}$ average temperature and its altitude is $1400 \mathrm{~m}$ above sea level. Tepi campus is among the three campuses of Mizan-Tepi University (two campuses found in Mizan-Aman) and it was established in 2006GC. According to information of the student's and alumni directorate of Tepi campus, under College of Natural and computational sciences, College of Engineering Technolgy and School of Computing and Informatics, there are 16 departments with a total of 5739 students of which, 4188 are males [Personal communication].

\section{Study variables}

The dependent variables in this study were knowledge, attitude and practice of students toward YFRHS, while the explanatory variables were sex, age, region, religion, mother's education, father's education availability of YFRHS in local area, and source of information.

\section{Study design and population}

A public University-based cross sectional analysis was made to assess the knowledge, attitude and practices of MTU-Tepi campus students towards youth friendly services. All students of MTU-Tepi campus under two colleges (College of Natural and Computational science, and College of Engineering and Technology) and one school (School of Computing and Informatics) were considered. All regular students in the Tepi campus selected as target population of this study. There is homogeneity among the study population, and in addition, the target population was known, therefore the simple random sampling technique used to select the sample from target population by applying lottery method.

\section{Inclusion and exclusion criteria}

All class attending regular and volunteer students to enroll in the study are included, whereas, those seriously ill and not volunteer to participate are excluded from the study.

\section{Sample size determination}

The sample size was calculated using a single-population proportion formula using the parameters: confidence level $95 \%\left(Z_{\frac{\alpha}{2}}=1.96\right)$, margin of error $5 \%(d=0.05)$, and assuming the prevalence of having knowledge of YFHS $50 \%(p=0.5)$. Then the sample size $(n)$ was determined as follows:

$$
n=\frac{\left(z_{\frac{\alpha}{2}}\right)^{2} p(1-p)}{d^{2}}, \quad n=\frac{(1.96)^{2} 0.5(1-0.5)}{0.0025}=385
$$

By considering $11 \%$ of none response rate, the sample size was calculated as 428 .

\section{Data collection procedure and instrument}


Basic socio-demographic and socio economic data and sexual related information were collected by using the pretested, semi-structured self-administered questionnaire after obtaining consent and voluntariness from each respondent.

\section{Statistical Data analysis}

The collected data were cleared, coded and analyzed using SPSS version 20. For statistical analysis, from descriptive statistics: frequency and percentage, and from inferential statistics: chi-square and multiple logistic regression with odd ratio (OR) were applied to identify the significant factors. The predictor variables those were significant in the univariable analysis at $25 \%$ ( $p$-value $<0.25$ ) level of significance were included in the multiple logistic regression analysis. The estimated odds ratios (OR) and 95\% confidence intervals with $p$-value less than $5 \%$ indicates that the variables are statistical significant in multivariable analysis.

\section{Operational definition of Terms}

Youth is the period between childhood and adulthood that involves unique physiological, psychological, cognitive, social, and economic changes, describing individuals in the age range of 15 and 24 years. Youthfriendly Health Services: are services that are considered as sociable, ideal and suitable for providing solutions for the various health concerns of young people. Youth-friendly Centers: are any health facility that provides friendly services to the youth $[4,7,17]$.

\section{Results}

\section{Socio-demographic characteristics of study participants}

From a total of 428 students enrolled in the study, 258(60.30\%) were females and 209(48.80\%) were in the age group of 21-22 years. Most of the students are from Oromia 105(24.5\%), Addis Ababa 71(16.6\%) and SNNPRS $70(16.4 \%)$. Educational background of $145(33.9 \%)$ and $96(22.4 \%)$ of the mother and father of students were uneducated, while $102(23.8 \%)$ and $80(18.7 \%)$ of their parents were attended primary school, respectively. Most of students in the study were followers of Orthodox [126(29.4\%)] and Protestant religions [117(27.3\%)] (Table 1). 
Table 1

Socio-demographic characteristics and family background of Students, $2019(n=428)$

\begin{tabular}{|c|c|c|}
\hline Variables & Categories & Frequency(n(\%)) \\
\hline \multirow[t]{2}{*}{ Sex } & Female & $258(60.3)$ \\
\hline & Male & $170(39.7)$ \\
\hline \multirow[t]{3}{*}{ Age } & $18-20$ & 71(16.6) \\
\hline & $21-22$ & $209(48.8)$ \\
\hline & $23-24$ & $148(34.6)$ \\
\hline \multirow[t]{7}{*}{ Region } & Addis ababa & 71(16.6) \\
\hline & Tigiray & $28(6.5)$ \\
\hline & Amhara & $55(12.9)$ \\
\hline & SNNPRS & $70(16.4)$ \\
\hline & Oromia & $105(24.5)$ \\
\hline & Gambela & $30(7.0)$ \\
\hline & Other & $69(16.1)$ \\
\hline \multirow[t]{5}{*}{ Religion } & Orthodox & $126(29.4)$ \\
\hline & Protestant & $117(27.3)$ \\
\hline & Catholic & $64(15.0)$ \\
\hline & Muslim & $90(21.0)$ \\
\hline & Other & $31(7.2)$ \\
\hline \multirow[t]{5}{*}{ Mother's Educational status } & Uneducated & 145(33.9) \\
\hline & Primary & $102(23.8)$ \\
\hline & Secondary & $71(16.6)$ \\
\hline & Diploma & $41(9.6)$ \\
\hline & Degree \& above & $69(16.1)$ \\
\hline \multirow[t]{5}{*}{ Father's Educational status } & Uneducated & $96(22.4)$ \\
\hline & Primary & $80(18.7)$ \\
\hline & Secondary & $112(26.2)$ \\
\hline & Diploma & $70(16.4)$ \\
\hline & Degree and Above & $70(16.4)$ \\
\hline Knowledge & No & $237(55.4)$ \\
\hline
\end{tabular}




\begin{tabular}{|lll|} 
& Yes & $191(44.6)$ \\
Attitude & Negative & $172(40.2)$ \\
\cline { 2 - 3 } Practices & Positive & $256(59.8)$ \\
& No & $262(61.2)$ \\
\cline { 2 - 2 } & Yes & $166(38.8)$ \\
\hline
\end{tabular}

\section{Knowledge, attitude and practice of respondents}

From the total participants, $150(35 \%)$ of the students have no knowledge of the youth friendly health service (YFHS) (Table 2), and never heard of any information about YFRHS. Majority (220(51.4\%)) of them reported having no any YFRHS in their surroundings while $58(13.6 \%)$ do not know whether there is the service or not. For $131(30.6 \%)$ and $151(35.3 \%)$ of students their friends and school teachers were the major sources of information about YFHS, respectively. The role of media as a source of information about YFHS is limited to about $21 \%$ (4.7\% from newspaper and $17.8 \%$ from different media). Two hundred forty eight $(57.9 \%)$ of the respondents answered that family planning and contraception were services provided at YFRHS centres (Table 2).

Table 2

Knowledge of youth friendly service among students of MTU-Tepi campus, 2019 (n=428)

\begin{tabular}{|c|c|c|}
\hline Characteristics & & Frequency (\%) \\
\hline \multirow[t]{2}{*}{ Ever heard of any information about YFRHS? } & Yes & $237(55.4 \%)$ \\
\hline & No & 150(35) \\
\hline \multirow[t]{3}{*}{ Any YFRH service in your area? } & Yes & $150(35)$ \\
\hline & No & $220(51.4)$ \\
\hline & I don't know & $58(13.6)$ \\
\hline \multirow[t]{4}{*}{ Source of information about YFRHS? } & Friends & 131(30.6) \\
\hline & School teachers & $151(35.3)$ \\
\hline & Media & $96(22.4)$ \\
\hline & Health institutions & $56(13.1)$ \\
\hline \multirow[t]{3}{*}{ What are the services given at YFRHS providers? } & Family planning and contraception & $248(57.9)$ \\
\hline & VCT service & $155(36.2)$ \\
\hline & Treatment of STIs & $23(5.8)$ \\
\hline
\end{tabular}

About $53 \%$ of the respondents believe that provision of contraception for a young person is obligatory and $53.3 \%$ argue that every young person should aware of YFRHS. From a total students $72.4 \%$ of the respondents disagrees that females are not the only one to use YFRHS (Table 3). Out of 428 respondents, $57.9 \%, 59.3 \%$, and 
$36.4 \%$ had never been practiced services related to VCT, family planning and contraception and treatment of STIs at YFRHS, respectively (Table 4).

Table 3

Attitudes of students towards Youth Friendly Health Service $(n=428)$

\begin{tabular}{|c|c|c|c|c|c|c|}
\hline \multirow[t]{2}{*}{ No. } & Characteristics & $S D *$ & Disagree & Neutral & Agree & $S A^{*}$ \\
\hline & & n (\%) & n (\%) & n (\%) & n (\%) & n (\%) \\
\hline 1. & $\begin{array}{l}\text { Unmarried youth have to visit } \\
\text { YFRHS centres }\end{array}$ & $38(8.9)$ & $88(20.6)$ & $96(22.4)$ & $172(40.2)$ & $34(7.9)$ \\
\hline 2. & $\begin{array}{l}\text { The provision of contraception for } \\
\text { young people is obligatory }\end{array}$ & $28(6.5)$ & $110(25.7)$ & $62(14.5)$ & $208(48.6)$ & $20(4.7)$ \\
\hline 3. & $\begin{array}{l}\text { Every young person should aware } \\
\text { of YFRHS }\end{array}$ & $6(1.4)$ & $58(13.6)$ & $108(25.2)$ & 144(33.6) & $112(26.2)$ \\
\hline 4. & $\begin{array}{l}\text { Only females should use youth } \\
\text { friendly health service }\end{array}$ & $62(14.5)$ & $248(57.9)$ & $54(12.6)$ & $50(11.7)$ & 14(3.3) \\
\hline 5. & $\begin{array}{l}\text { Each unmarried young female } \\
\text { pregnant can use safe abortion } \\
\text { care }\end{array}$ & $50(11.7)$ & $190(44.4)$ & $88(20.6)$ & $90(21.0)$ & $10(2.3)$ \\
\hline 6. & Every youth should use VCT service & $60(14)$ & $134(31.3)$ & $94(22.0)$ & $126(29.4)$ & $14(3.3)$ \\
\hline 7. & $\begin{array}{l}\text { Provission of YFRHS in the health } \\
\text { institution are adequate }\end{array}$ & $322(75.2)$ & $57(13.3)$ & $49(11.4)$ & - & - \\
\hline 8. & $\begin{array}{l}\text { Provission of YFRHS in both public } \\
\text { and private health facilities should } \\
\text { be free }\end{array}$ & - & - & $36(8.4)$ & - & 392(91.6) \\
\hline
\end{tabular}

Table 4

Practice of utilization of Young friendly reproductive health services among students of MTU-Tepi campus, $2019(n=428)$

\begin{tabular}{|lll|}
\hline Characteristics & Categories & Frequency(\%) \\
\hline Family planning and contraception & No & $254(59.3)$ \\
\cline { 2 - 3 } & Yes & $174(40.7)$ \\
\hline Voluntary Counseling Test (VCT) & No & $248(57.9)$ \\
\cline { 2 - 3 } & Yes & $180(42.1)$ \\
\hline Treatment of STI & No & $156(36.4)$ \\
\cline { 2 - 3 } & Yes & $272(63.6)$ \\
\hline
\end{tabular}

\section{Association of knowledge of students and explanatory variables}


The results of the chi-square test of association revealed that sex of student, age of student, mother education status, father education status, availability of service providers in the student's area and source of information had statistical significant association with knowledge of students toward YFHS as shown in the (Table 5). The region and religion of students had no any statistical significant relationship.

Table 5

Association of knowledge of YFHS among students and explanatory variables

\begin{tabular}{|llll|}
\hline Variables & Chi-square test & Degree freedom & P-value \\
\hline Sex of student & 2.614 & 1 & $0.010^{\star}$ \\
\hline Age of student & 19.592 & 2 & $0.000^{\star}$ \\
\hline Region of student & 6.546 & 6 & 0.365 \\
\hline Mother Education status & 9.167 & 4 & $0.007^{\star}$ \\
\hline Father Education status & 16.199 & 4 & $0.003^{\star}$ \\
\hline Any service in the area & 30.105 & 2 & $0.000^{\star}$ \\
\hline Source of information & 33.546 & 4 & $0.000^{\star}$ \\
\hline Religion of student & 5.753 & 4 & 0.218 \\
\hline
\end{tabular}

\section{Knowledge, attitude and practices and associated factors of Youth Friendly Health Services among respondents}

The results of multiple logistic regression analysis using forward variable selection method of the parameter estimates presented in the (Table 6). This finding revealed that sex, age, mother education, father education, availability of YFRS in the area, source of information about YFRHS and religion had statistical significant effect on the knowledge, attitude and practices of students toward YFHS. In this regard, male students were more likely to have knowledge and practicing experiences $(O R=1.847, p$-value $=0.015)$ and $(O R=1.821, p$-value $=0.017)$, respectively, however they had less likely positive attitudes than female $(O R=0.519, p$-value $=0.010)$. 
Table 6

Multiple Logistic Regression results of Knowledge, Attitude and Practice of Students toward YFRHS

\begin{tabular}{|c|c|c|c|c|c|c|c|}
\hline & & Knowledge & & Attitude & & Practice & \\
\hline variables & categories & $\begin{array}{l}\text { OR }[95 \% \mathrm{Cl} \\
\text { for OR] }\end{array}$ & $\begin{array}{l}P \text { - } \\
\text { value }\end{array}$ & $\begin{array}{l}\text { OR[95\% Cl } \\
\text { for OR] }\end{array}$ & $\begin{array}{l}\mathrm{P} \text { - } \\
\text { value }\end{array}$ & $\begin{array}{l}\text { OR }[95 \% \mathrm{Cl} \text { for } \\
\text { OR] }\end{array}$ & $\begin{array}{l}\mathrm{P}- \\
\text { value }\end{array}$ \\
\hline \multirow[t]{2}{*}{ Sex } & Female & Ref. & & & & & \\
\hline & Male & $\begin{array}{l}1.847(1.124- \\
3.034)\end{array}$ & $0.015^{\star}$ & $\begin{array}{l}0.519(0.315- \\
0.856)\end{array}$ & $0.010 *$ & $\begin{array}{l}1.821(1.114- \\
2.975)\end{array}$ & $0.017^{*}$ \\
\hline \multirow[t]{3}{*}{ Age } & $18-20$ & Ref. & & & & & \\
\hline & $21-22$ & $\begin{array}{l}2.732(1.405- \\
5.313)\end{array}$ & $0.003^{\star}$ & $\begin{array}{l}0.418(0.212- \\
0.827)\end{array}$ & $0.012^{\star}$ & $\begin{array}{l}2.275(1.164- \\
4.447)\end{array}$ & $0.016^{*}$ \\
\hline & $23-24$ & $\begin{array}{l}4.345 \\
(1.742- \\
7.168)\end{array}$ & $0.002^{\star}$ & $\begin{array}{l}1.260(0.611- \\
2.599)\end{array}$ & 0.531 & $\begin{array}{l}0.901(0.443- \\
1.836)\end{array}$ & 0.775 \\
\hline \multirow[t]{7}{*}{ Region } & $\begin{array}{l}\text { Addis } \\
\text { Ababa }\end{array}$ & Ref. & & & & & \\
\hline & Tigiray & $\begin{array}{l}0.314(0.110- \\
0.896)\end{array}$ & $0.030 *$ & $\begin{array}{l}1.561(0.520- \\
4.686)\end{array}$ & 0.427 & $\begin{array}{l}0.498(0.167- \\
1.482)\end{array}$ & 0.210 \\
\hline & Amhara & $\begin{array}{l}1.210 \\
(0.550- \\
2.664)\end{array}$ & 0.635 & $\begin{array}{l}1.043(0.473- \\
2.302)\end{array}$ & 0.916 & $\begin{array}{l}0.779(0.360- \\
1.687)\end{array}$ & 0.527 \\
\hline & SNNPR & $\begin{array}{l}0.753(0.358- \\
1.582)\end{array}$ & 0.453 & $\begin{array}{l}1.104(0.519- \\
2.349)\end{array}$ & 0.797 & $\begin{array}{l}0.646(0.305- \\
1.365)\end{array}$ & 0.252 \\
\hline & Oromia & $\begin{array}{l}0.452 \\
(0.207- \\
0.986)\end{array}$ & $0.046 *$ & $\begin{array}{l}1.900(0.860- \\
4.195)\end{array}$ & 0.112 & $\begin{array}{l}0.495(0.228- \\
1.073)\end{array}$ & 0.075 \\
\hline & Gambela & $\begin{array}{l}0.667(0.229- \\
1.941)\end{array}$ & 0.457 & $\begin{array}{l}1.293(0.440- \\
3.801)\end{array}$ & 0.640 & $\begin{array}{l}0.699(0.246- \\
1.987)\end{array}$ & 0.501 \\
\hline & Other & $\begin{array}{l}0.812(0.393- \\
1.676)\end{array}$ & 0.573 & $\begin{array}{l}0.967(0.465- \\
2.011)\end{array}$ & 0.928 & $\begin{array}{l}0.799(0.387- \\
1.650)\end{array}$ & 0.544 \\
\hline \multirow{5}{*}{$\begin{array}{l}\text { Mother } \\
\text { Education } \\
\text { status }\end{array}$} & uneducated & Ref. & & & & & \\
\hline & Primary & $\begin{array}{l}1.274(1.139- \\
2.541)\end{array}$ & $0.000 *$ & $\begin{array}{l}3.087(1.557- \\
6.121)\end{array}$ & $0.001^{\star}$ & $\begin{array}{l}2.541(1.160- \\
5.569)\end{array}$ & $0.000 *$ \\
\hline & Secondary & $\begin{array}{l}1.413(1.185- \\
3.919)\end{array}$ & $0.030 *$ & $\begin{array}{l}2.485(1.108- \\
5.571)\end{array}$ & $0.027 *$ & $\begin{array}{l}3.279(1.516- \\
7.094)\end{array}$ & $0.019 *$ \\
\hline & Diploma & $\begin{array}{l}1.085(0.398- \\
2.957)\end{array}$ & 0.873 & $\begin{array}{l}0.805(0.294- \\
2.208)\end{array}$ & 0.674 & $\begin{array}{l}2.451(1.034- \\
5.813)\end{array}$ & 0.510 \\
\hline & $\begin{array}{l}\text { Degree \& } \\
\text { Above }\end{array}$ & $\begin{array}{l}0.678(0.311- \\
1.477)\end{array}$ & 0.328 & $\begin{array}{l}1.348(0.617- \\
2.944)\end{array}$ & 0.454 & $\begin{array}{l}7.125(2.867- \\
17.710)\end{array}$ & 0.595 \\
\hline $\begin{array}{l}\text { Father } \\
\text { Education }\end{array}$ & uneducated & Ref. & & & & & \\
\hline
\end{tabular}




\begin{tabular}{|c|c|c|c|c|c|c|c|}
\hline & & Knowledge & & Attitude & & Practice & \\
\hline & Primary & $\begin{array}{l}2.605(1.191- \\
5.699)\end{array}$ & $0.017^{*}$ & $\begin{array}{l}0.574(0.262- \\
1.256)\end{array}$ & 0.165 & $\begin{array}{l}2.541[1.160- \\
5.569)\end{array}$ & 0.020 * \\
\hline & Secondary & $\begin{array}{l}3.544(1.643- \\
7.648)\end{array}$ & $0.001^{*}$ & $\begin{array}{l}0.318(0.147- \\
0.689)\end{array}$ & $0.004^{*}$ & $\begin{array}{l}3.279[1.516- \\
7.094)\end{array}$ & $0.003^{*}$ \\
\hline & Diploma & $\begin{array}{l}2.725 \\
(1.138- \\
6.523)\end{array}$ & $0.024^{*}$ & $\begin{array}{l}0.428(0.179- \\
1.024)\end{array}$ & 0.057 & $\begin{array}{l}2.451[1.034- \\
5.813)\end{array}$ & $0.042 *$ \\
\hline & $\begin{array}{l}\text { Degree and } \\
\text { Above }\end{array}$ & $\begin{array}{l}8.308 \\
(3.299- \\
20.923)\end{array}$ & $0.000 *$ & $\begin{array}{l}0.135(0.053- \\
0.341)\end{array}$ & $0.000 *$ & $\begin{array}{l}7.125[2.867- \\
17.710)\end{array}$ & 0.000 * \\
\hline Any service & No & Ref. & & & & & \\
\hline & Yes & $\begin{array}{l}3.230(1.908- \\
5.469)\end{array}$ & $0.000 *$ & $\begin{array}{l}0.392(0.230- \\
0.668)\end{array}$ & $0.001^{*}$ & $\begin{array}{l}2.475(1.469- \\
4.168)\end{array}$ & $0.001 *$ \\
\hline & $\begin{array}{l}\text { I don't } \\
\text { know }\end{array}$ & $\begin{array}{l}2.559(1.216- \\
5.385)\end{array}$ & $0.013^{*}$ & $\begin{array}{l}0.345(0.162- \\
0.733)\end{array}$ & $0.006^{*}$ & $\begin{array}{l}1.476(0.706- \\
3.086)\end{array}$ & 0.301 \\
\hline Source of & Parent & Ref. & & & & & \\
\hline & friend & $\begin{array}{l}0.927(0.430- \\
1.995)\end{array}$ & 0.846 & $\begin{array}{l}1.733(0.805- \\
3.730)\end{array}$ & 0.160 & $\begin{array}{l}0.738(0.346- \\
1.572)\end{array}$ & 0.431 \\
\hline & teacher & $\begin{array}{l}1.657(0.774- \\
3.544)\end{array}$ & 0.193 & $\begin{array}{l}0.663(0.312- \\
1.408)\end{array}$ & 0.285 & $\begin{array}{l}1.691(0.802- \\
3.565)\end{array}$ & 0.168 \\
\hline & News paper & $\begin{array}{l}0.119(0.027- \\
0.529)\end{array}$ & $0.005^{*}$ & $\begin{array}{l}7.776(1.764- \\
34.290)\end{array}$ & $0.007 *$ & $\begin{array}{l}0.151(0.034- \\
0.668)\end{array}$ & $0.013^{*}$ \\
\hline & media & $\begin{array}{l}0.288 \\
(0.112- \\
0.738)\end{array}$ & $0.009 *$ & $\begin{array}{l}5.177(1.944- \\
13.787)\end{array}$ & $0.001^{*}$ & $\begin{array}{l}0.305(0.119- \\
0.785)\end{array}$ & $0.014^{*}$ \\
\hline Religion & Orthodox & Ref. & & & & & \\
\hline & Protestant & $\begin{array}{l}0.981(0.527- \\
1.823)\end{array}$ & 0.951 & $\begin{array}{l}1.455(0.781- \\
2.711)\end{array}$ & 0.237 & $\begin{array}{l}0.936(0.508- \\
1.724)\end{array}$ & 0.832 \\
\hline & Catholic & $\begin{array}{l}0.713(0.333- \\
1.527)\end{array}$ & 0.384 & $\begin{array}{l}1.696(0.790- \\
3.639)\end{array}$ & 0.175 & $\begin{array}{l}0.728(0.341- \\
1.554)\end{array}$ & 0.412 \\
\hline & Muslim & $\begin{array}{l}0.807(0.404- \\
1.609)\end{array}$ & 0.542 & $\begin{array}{l}1.590(0.792- \\
3.193)\end{array}$ & 0.192 & $\begin{array}{l}0.796(0.401- \\
1.579)\end{array}$ & 0.514 \\
\hline & Other & $\begin{array}{l}0.314(0.110- \\
0.896)\end{array}$ & $0.030 *$ & $\begin{array}{l}7.582(2.318- \\
24.796)\end{array}$ & $0.001^{*}$ & $\begin{array}{l}0.197(0.062- \\
0.624)\end{array}$ & $0.006^{*}$ \\
\hline
\end{tabular}

Students whose age ranges 21-22 had knowledge 2.732 times and age ranges 23-24 had knowledge 4.345 times more likely than $18-20$ years $(O R=2.732, p$-value $=0.003)$ and $(O R=4.345, p$-value $=0.002)$ respectively. Students in age group 21-22 were 2.275 times more likely to practice YFRHS compared to respondents in the 
age group of 18-20 years. Students from Tigiray and Oromia regions were less likely to had knowledge about YFRHS $(O R=0.314, p$-value $=0.030)$ and $(O R=0.452$, $p$-value $=0.046)$ compared to students from Addis Ababa city administration (Table 6).

The odds ratio for students from primary school educated mothers were $(O R=1.274, p$-value $=0.000),(O R=$ 3.087 , $p$-value $=0.001)$ and $(O R=2.541$, $p$-value $=0.000)$, which implies that students from primary school educated mothers were $1.274,3.087$ and 2.541 times more likely to have knowledge, positive attitude and practice of YFHS than uneducated mothers respectively. Students from secondary school educated mothers had odd ratios $(O R=1.413, p$-value $=0.030),(O R=2.485$, $p$-value $=0.027)$ and $(O R=3.279$, $p$-value $=0.019)$, which implies that students from secondary school educated mothers were 1.413, 2.485 and 3.279 times more likely to have the knowledge, positive attitude and practices of YFRHS than having uneducated mothers, respectively.

The odds ratio for students from fathers of different educational backgrounds had statistical significant effect on knowledge, attitude and practicing of YFRHS. As shown in the Table 6, students whose fathers were educated primary and above had odds ratio greater than one, and this implies that those students were more likely to have knowledge and positive attitude of YFRHS compared to uneducated father.

Students having YFRHS in their surroundings were more likely to had knowledge and practicing experience (OR $=3.230, \mathrm{p}$-value $=0.000)$ and $(O R=2.475, p$-value $=0.001)$ compared to students not having any service in their surroundings, respectively (Table 6).

Students who get information from newspaper and media were 0.119 and 0.288 times less likely to had knowledge and practicing experiences $(O R=0.119, p$-value $=0.005)$ and $(O R=0.288$, $p$-value $=0.009)$ than students who get information from their parents. The odds ratio for students who get information from newspaper $(O R=7.776, p$-value $=0.007)$ and media $(O R=5.177, p$-value $=0.001)$, which implies that students who get information from newspaper and media were more likely to have positive attitude of YFHS than students who get information from their parents (Table 6).

\section{Discussion}

Out of the students of Mizan-Tepi University Tepi Campus enrolled in the study, 220(51.4\%) reported having no acces to any YFRHS in their locality and this was comparable with previous studies conducted in Jimma, 47.1\% [18]. But it was much higher than a study conducted in Bahir Dar, 13.6\% [19] Adiss Ababa 40\% [20], and community based study in Jimma 41\% [18] and Harar 36\% [21].

For $131(30.6 \%)$ and $151(35.3 \%)$ of the respondents, their friends and school teachers were the major sources of information about YFRHS, respectively, and this is quite similar with findings from Mekelle Town and Bahir Dar, that reported the media outlets as a source of information is for $35.5 \%$ of the students [19]. Whereas, finding of this study is in contrast to studies done in Nigeria [22], Tanazania [23] and Ghana [1], that indicates parents, close friends and peers of youths are the most common sources of information.

The major sources of information about YFRHS were different medias, in our study about $21 \%$ of participants got information from different medias and this was in agreement with a study done in Harar that showed media as source of information for $22.8 \%$ participants [24]. However, this finding is less than a study in Bahir Dar and Mekelle $(35.5 \%)[19,15]$. Majority $(55.4 \%)$ of respondents lack basic information and knowledge of YFHRS and 
this was similar with a study in Meda Wolabu University students [16]. However, it was found much less than a research from Hadiya Ethiopia (78.5\%) [25]. On the other hand, $27.6 \%$ of the respondents believed that females are the only one to use youth friendly health service and this agrees with researches done in Moldova [9].

Of a total of 428 participants, only $49 \%$ had utilized YFRHS, which is higher than a study report from Bahir Dar (32\%) [19]. Treatment of STIs services (63.6\%) and VCT (42.1\%) were the most utilized services by the study cases. However, family planning and contraception $(40.7 \%)$ was a less utilized service at YFRHS centre. This was in contrast to the finding in Hadiya Zone, Ethiopia [25], that reported VCT 343(68.9\%), and contraception $321(64.5 \%)$, as the most utilized YFRHS. One of the most reported reasons by the students for not utilizing the services was the unavailabilty of the service in their locality (51.1\%), and less availability of services even in some of the areas where the service provider is available, and this was also reported in West Gojjam Zone of Ethiopia [13]. Other study from Bahir Dar indicated inconvenience hours and fear of being seen by parents, colleagues, neighbors or other people as roadblocks in utilizing reproductive health services [19]. Among the respondents, condom [195(45.6\%)]and emergency pills [169(39.5\%)] are the most commonly used contraceptive methods. Ths finding was supported with other studies conducted in different parts of the Ethiopia[7, 13, 14] and beyond like South Africa and Tanzania [23, 26, 27]. And, this requires a great attention of both governmental and non-governmemtal organizations working in provision of YFRHS across parts of Ethiopia. On chi-square test analysis, the factors that were found to be significantly associated with knowledge of students toward YFRHS were sex, age, mother's education and father's educational status, availability of any YFRH service in the respondents' area and source of information. This was in agreement with studies conducted in Bale[28] and Wollisso [29].

Male students had more knowledge and practicing experience than female student and this is in line with studies done in South Gondar [30], Gujarat India[31] and China [32]. This might be lack of awareness given for female students on YFRHS or lack of service giving facility in their surroundings nearby. However, it is opposing to the study done in East Gojjam zone, Ethiopia [33]. Students in the age group 21-22 were 2.732 times and in age group 23-24 were 4.345 times more likely to have knowledge compared to student in the age group of 1820 years, respectively, Moreover, students in the age group of 21-22 years were 2.275 times more likely experienced YFHS compared to students in the age group of 18-20 years. This study is in agreement with studies conducted in Bahir Dari [34], Jimma city [18], India[35] and East Gojjam [33]. Following the growth of students' in age, there is a subsequent increase in having knowledge about YFHS, this might be due to information gap about the service on time. However, it contradicts with study done using multi-country data analysis in China [32].

Students whose permament residence was Tigiray and Oromia regions had less knowledge about YFHS compared to Addis Ababa city administration. This could be due to student from urban had more YFHS offering facility access than students from rural parts of the country. As Addis Ababa is the capital city of Ethiopia and also there are many governmental and non-governmental health facilities. Mother and father education status had statistical significant effect on the knowledge, attitude and practice of students toward YFHS. As shown in this finding, when the mother and father education level increased the knowledge, attitude and practice of students toward YFRHS also increased. This study is in line with study conducted in Awabel district northwest Ethiopia [36] and it is contradicting with the study done in south Gondar [30]. 
Students who had YFRHS access in their surroundings were 3.23 times more likely to have knowledge and 2.475 times more likely practicing experience about YFRHS compared to students who had no any service in their surroundings respectively this study is consistent with a studies done in Hadiya Zone of Ethiopia [25] and Kenya [37]. Having this information, it can be expected as youths becoming more familiar with the service settings as well as type of services offered, and they will freely adopt to what type of the service they have to use. Students who get information about YFRHS from their parents are more likely to have knowledge compared to students who get from different media. This finding agreed with study conducted in Awabel district northwest Ethiopia [36]. Students who get information from newspaper were 7.776 times more likely to have positive attitude compared to students who get information from their parents. This study is consistent with study conducted in Jimma city [18]. Participants who get information from media were 5.177 times more likely to have positive attitudes compared to students who get information from parents. According to practicing experience of YFRHS, this study revealed that there is opposite outcomes for practice and attitudes based on the source of information. This might be due to students had information about the YFRHS, but no any services given for them.

\section{Conclusion}

This study revealed that the study respondents knowledge, attitude and utilization of youth friendly reproductive health service were not good enough. Therefore, much more effort is needed from all concerned bodies in designing and implementing appropriate provision of information through the use of media outlets and incorporating into the curriculum education schools and universities influence the knowledge, attitudes and utilization of youth friendly services. Moreover, further cooperative efforts should be done by both governmental and non- governmental organizations in making YFRHS in qualities and accessibility that is appropriate for young people's demand.

\section{Abbreviations}

MTU: Mizan-Tepi University

YFRHS: Youth Friendly Reproductive Health Service

HIV: Human Immuno-defficiency Virus

STI: Sexual Transimiting Infections

VCT: Voluneeter Counsiling Test

SNNPRS: Southern Nations Nationalities and Peoples Regional State

\section{Declarations}

\section{Ethics approval and consent to participate}

The Institutional Ethical Clearance Committee of Mizan-Tepi University had ethically cleared the study while permissions were obtained from the Mizan-Tepi University Tepi Campus, Chief Directorate, and each college and 
school. Moreover, an informed written consent was obtained from each study participants and confidentiality of the data was assured.

\section{Consent for publication}

Not applicable.

\section{Availability of data and materials}

The datasets used in these study available from the corresponding author on reasonable request.

\section{Competing interest}

The authors declare that there is no competing interests.

\section{Funding}

This study was funded by Mizan-Tepi University.

\section{Authors' contributions}

Conception and design: Samuel Getachew and Abel Mandefro, acquisition of data: Samuel Getachew, Abel Mandefro, Lema Abate and and Abiyot Asres; analysis and interpretation of data: Samuel Getachew and Lema Abate; drafting of the manuscript: Samuel Getachew and Lema Abate; critical revision of the manuscript for important intellectual content: Samuel Getachew, Abel Mandefro, Lema Abate and and Abiyot Asres. All authors revised and approved the manuscript.

\section{Acknowledgment}

We would like to thank Mizan-Tepi University for the funding.

\section{References}

1. Anokye M., Knowledge, Attitudes and Perceptions of Youth-Friendly Health Services among Adolescents in the Ashaiman District of Ghana, Acra: University of Ghana, 2019.

2. FHI/USAID, "Assessment of Youth Reproductive Health Programs in Ethiopia, Youth Net Institute of Development Research: Lecture papers on population and development," Addis Ababa, Ethiopia, 2015.

3. J. Senderowitz, "Making Reproductive Health Services. FOCUS on Young Adults. Youth Friendly. Research, Program and Policy Series," Washington DC, 1999.

4. WHO, "World Health Organization. Adolescent friendly health services: An agenda for change.," WHO, Geneva, 2012.

5. UN, "World Population Monitoring Adolescents and Youth: A Concise Report of United Nations Department of," UN, New York, 2012.

6. W.S. E. M. A. v. d. K. K. Madeleen, "Youth friendly health services in multiple perspectives.," Amsterdam, 2014. 
7. FMOH, "National Adolescent and Youth Reproductive Health Strategy.," Federal Ministry of Health of Ethiopia, Addis Ababa, 2006.

8. G. J. N. S. Koon A. D., "Considerations for linking South Africa's Youth-friendlyServices to its community health worker programme," South African Journal of Child Health, pp. 8(3), 85-87., 2014.

9. B. S. C. M. I. V. Carai S., "Assessing youth-friendly-health-services and supporting planning in the Republic of Moldova," Reproductive health, p. 12(1): 98, 2015.

10. UNFPA, Assessment of Adolescents and Youth-Friendly Health Service Delivery in the East and Southern Africa Region., Johannesburg and Nairobi, 2017.

11. FMOH, " Ministry of Health Ethiopia. National adolescent and youth reproductive health strategy. 20112015," Federal ministry of Health, Addis Ababa, 2017.

12. FMOH., "Situational Analysis of Adolescent and Youth Health in Ethiopia," Federal Ministry of Health, Addis Abab, 2015.

13. A. G. D. G. Munea A., "Quality of youth friendly sexual and reproductive healthServices in West Gojjam Zone, North West Ethiopia: with special reference to the application of theDonabedian model," BMC Health Services Research, p. 20:245, 2020.

14. S. E. A. A. G. A. R. C. Yemaneh Y., "Assessment of the proportion andassociated factors of episiotomy at public health institutions of Axum Town, Tigray Region, North Ethiopia," Crit Care Obst Gyne, vol. 3, p. 11, 2017.

15. B. S. A. M. Kahsay K., "Utilization of Youth Friendly Services andAssociated Factors in Mekelle Town, Tigray, Northern Ethiopia," International Journal of Therapeutic applications, pp. Volume 33, 49-59, 2016.

16. T. M. Setegn M., "Sexual and reproductive health problems and service needs of universitystudents in south east Ethiopia: Exploratory qualitative study," Science Journal of Public Health, vol. 1(4), pp. 184-188, 2013.

17. UNICEF, "Working for and with Adolescents - Some UNICEF examples," UNICEF, Geneva, 2002.

18. M. Y. G. Ayalew T., "Adolescent reproductive health services in Jimma City: Accessibility and Utilization," Ethiop J Health Sci., p. 19:2, 2009.

19. A. W. Abebe M., "Utilization of Youth Reproductive Health Services and Associated Factorsamong High School Students in Bahir Dar, Amhara Regional State, Ethiopia," Open Journal of Epidemiology, pp. 4, 69-75. http://dx.doi.org/10.4236/ojepi.2014.42012, 2014.

20. D. N. D. G. Habte D., "Assessment of the Utilization of Pre-marital testing services anddeterminants of VCT in Addis Ababa.," Ethiopian Journal of Health development, pp. 20(1): 18-23, 2006.

21. S. T. E. G. K. A. Motuma A., "Utilization of youth friendly services and associatedfactors among youth in Harar town, east Ethiopia: a mixed method study," BMC health services research, vol. 16(1), p. 272, 2016.

22. O. E. A. A. K. Y. O. G. O. O. Ololade W K., "Youth friendly health services in a rural community of Lagos, Nigeria: are theyouths receptive?," Int J Adolesc Med Health, pp. DOI 10.1515/ijamh-2015-0095, 2016.

23. F. P. Alliance A.Y., "Youth friendly sexual and reproductive health services: An assessment of facilities," African Youth Alliance/Pathfinder International., Dar es Salaam:, 2003.

24. Motuma A., "Youth-friendly health services utilization and factors in Harar," Ethiopia. Harar Bulletin of Health Sciences, vol. 4, pp. 15-21., 2012.

25. Helamo et al., "Utilization and Factors Affecting Adolescents and Youth Friendly Reproductive Health Services among Secondary School Students in Hadiya Zone, Southern Nations, Nationalities and Peoples 
Region, Ethiopia," Int J Pub Health Safe, p. 2:4, 2017.

26. W. E. C. L. N. S. Geary R.S., "Evaluating youth-friendly health services:young people's perspectives from a simulated client study in urban South Africa," Global Health Action, pp. 8(1),26080, 2015.

27. H. G. P. M. C. C. M. A. Chilinda I., "Attitude of health care providers towards adolescent sexual and reproductive health services in developing countries: a systematic review," Health, p. 2014, 2014.

28. T. B. K. A. Kerbo A., "Youth Friendly Sexual and Reproductive Health Services tilization and Associated Factors in Bale Zone of Ethiopia: A Community Based Cross Sectional Study," J.Women's Health Reprod Med, vol. (2)1, p. 11, 2018.

29. D. T. Mekonnen Y., "KAP study on HIV/AIDS among adolescents and assessment ofavailable HIV/AIDS related services in Wolliso Woreda," Save The Children-USA, Addis Ababa, Ethiopia, 2005.

30. A. A. A. T. G. Addisu T A, "Reproductive health services utilization and its associated factors among secondary school youths in Woreta town, South Gondar, North West Ethiopia: a cross sectional study," BMC Res Notes, pp. 12:90, https://doi.org/10.1186/s13104-019-4129-z, 2019.

31. S. V. Kotecha PV, " Reproductive health awareness among rural school going adolescents of vadodara district, Gujarat, Indian," J Psychatry , p. 45(4):344-348, 2012.

32. L. E. Rani M., "Exploring the socioeconomic dimension of adolescent reproductive health: a multi-country analysis," Int Fam Plan Perspect, p. 30(3):110-117., 2004.

33. Abajobir S., "Reproductive health knowledge and services utilization among rural adolescents in east Gojjam zone, Ethiopia: a community-based cross-sectional study," BMC Health Services Research, pp. 14:138, http://www.biomedcentral.com/1472-6963/14/138, 2014.

34. W. A. Meskerem A., "Utilization of Youth Reproductive Health Services and Associated Factors among High School Students in Bahir Dar, Ethiopia," Open Journal of Epidemiology, pp. 4, 69-75, 2014.

35. Barkat A., "Adolescent reproductive health in Bangladesh: status. Programs and Issues: Policies.," 2003.

36. K. T. H. G. Ayehu A, "Level of Young People Sexual and Reproductive Health Service Utilization and Its Associated Factors among Young People in Awabel District, Northwest Ethiopia," PLoS ONE , p. 11(3): e0151613. doi:10.1371/journal.pone.0151613, 2016.

37. Ontiri KK. , "Factors influencing utilization of reproductive health services amongst young people in rift valley provincial hospital, Nakuru County- Kenya.," 2015. 